great preponderance of basic types. In the neighbourhood of Leipa occur numerous volcanic plugs and necks, composed of various alkaline basalts and trachydolerites, with tuffs of corresponding nature. In addition, dykes with a N.E.-S.W. direction are met with throughout the whole district. These have a wider petrographical range, and are discussed at length by the author. The most basic rocks of this series contain 50 per cent. of olivine, with melilite, biotite, haüyne, nepheline, \&c. To this type the author gives the name polzenite, but it does not seem to differ essentially from alnöite. From this extreme the rocks range through melilite- and nephelinebasalts, haüyne-basalts, and various trachydolerites to phonolites, the most acid term being a trachytoid phonolite very rich in sanidine. The silica percentage ranges from less than 30 to 58 . The whole assemblage of dyke-rocks is regarded as a single series, derived from a common magma by differentiation along definite lines. This conclusion is enforced by chemical analyses, fourteen in number, which yield smooth curves when plotted on a diagram. The author connects the differentiation with progressive crystallisation in the original magma, of trachydoleritic composition; and for a series of rock-types so related he proposes the term pexitropic.

Elements of Water Bacteriology with Special Reference to Sanitary Water Analysis. By S. C. Prescott and C. E. A. Winslow. Pp. xiv +3 r8. Third edition. (New York: John Wiley and Sons, Inc. ; London: Chapman and Hall, Ltd., I9I3.) Price 7s. 6d. net.

Attention has been directed in these columns to the previous editions of this work; to the first on July 7, 1904 (vol. 1xx., p. 221), and to the second on November 5, 1908 (vol. 1xxix., p. 6). In view of the important progress made during the last five years in sanitary bacteriology, the authors have thoroughly revised their work. Newer ideas on the effect of temperature upon the viability of bacteria in water are included; the recent recommendations of the committee on standard methods are discussed; the description of the isolation of specific pathogenes from water has been largely rewritten and much extended; and a new chapter on the application of bacteriology to the sanitary study of shellfish has been introduced.

Metallography. By Dr. Cecil H. Desch. Pp. $\mathrm{xi}+43 \mathrm{x}$. Second edition. (London: Longmans, Green and Co., I913.) Price 9s.

THE first edition of this book was reviewed in the issue of Nature for January 5, I9I I (vol. 1xxxv., p. 30I). In the present work the general plan and arrangement of the first edition remain unchanged, but the text has been revised, and the most important results of recent investigations have been incorporated. Important changes have been made in the treatment of the physical properties of alloys, and of the metallography of iron and steel.

$$
\text { NO. 2294, VOL. } 92]
$$

LETTERS TO THE EDITOR.

[The Editor does not hold himself responsible for opinions expressed by his correspondents. Neither can he undertake to return, or to correspond with the writers of, rejected manuscripts intended for this or any other part of NATURE. No notice is taken of anonymous communications.]

\section{The Piltdown Skull and Brain Cast.}

THE discovery of the fragments of the Piltdown skull has given rise to a problem of a new kind. In all former discoveries of the remains of ancient man the part of the skull actually found was intact, or, if broken, a sufficient number of pieces were recovered to render reconstruction an easy task. In the case of the Piltdown skull, although the greater part of the bony walls of the cranial cavity were found, a large area of the forehead and along the middle line of the roof of the skull are still missing. The problem that has to be solved is: How much is missing? The solution of the problem, as Dr. Smith Woodward realised when he commenced his work of

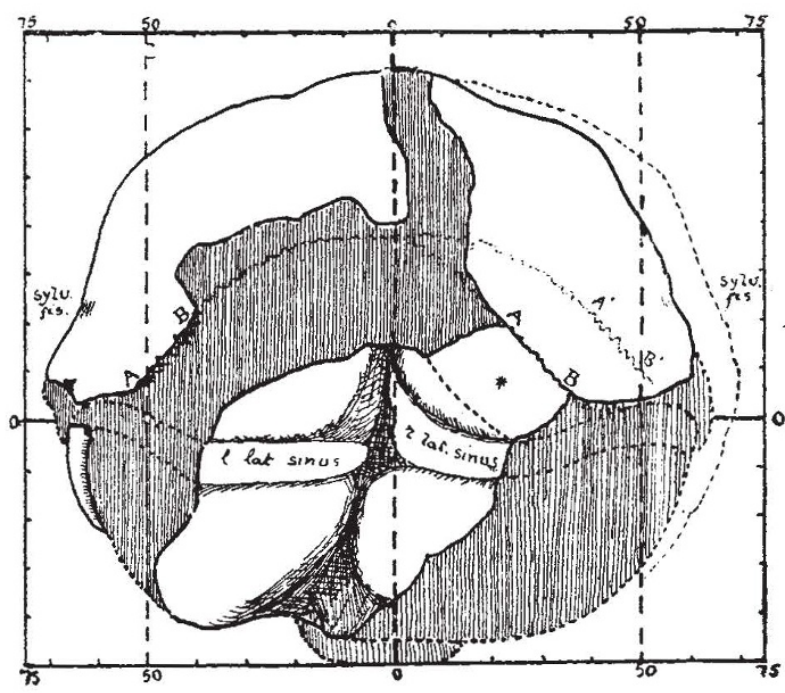

FiG. 1.-Occipital aspect of the brain-cast of the Piltdown skull as reconstructed by Dr. Smith Woodward. The parts missing in the skull are represented by vertical shading.

restoration, lies in the hinder or occipital wall of the skull. The fragment which Dr. Smith Woodward himself discovered gives a definite index to the width of the right half of the occipital bone, and also to the width of the hinder or occipital part of the head.

$\mathrm{It}$ is clear, then, that the first step in the reconstruction of the Piltdown skull must be an accurate adjustment of the parts which enter into the formation of the occipital wall. If a mistake is made in this initial step, then the error may become proportionately greater as one proceeds towards the region of the forehead. In my opinion. Dr. Smith Woodward has made a grave mistake in his restoration of the occipital region, and therefore the brain cast which he obtained from his reconstruction-the basis of Prof. Elliot Smith's preliminary note to the Gea logical Society-does not give an accurate representation of either the size or general form of the brain of Piltdown Man.

The nature of the problem and the manner of its solution will be made clear by the three accompanying figures. Fig. I represents the occipital aspect of the 